\title{
Early response of understory vegetation to wood ash fertilization in the sub boreal climatic zone of British Columbia
}

\author{
by Saskia C. Hart ${ }^{1,2}$, Hugues B. Massicotte ${ }^{1, *}$, P. Michael Rutherford ${ }^{1}$, Ché M. Elkin ${ }^{1}$ and Bruce J. Rogers ${ }^{3}$
}

\begin{abstract}
Wood ash can be used as a soil amendment in forest ecosystems to alleviate nutrient loss, ameliorate soil acidity, increase tree growth, and reduce landfilled waste. Two hybrid spruce (Picea glauca X engelmannii) plantations in interior British Columbia were treated with two types of bioenergy-produced wood ash (high carbon boiler ash and low carbon gasifier ash) with or without nitrogen fertilizer in a two-way factorial block design. Ash and nitrogen treatments were applied to $8.0 \mathrm{~m}$ radius plots at a rate of $5000 \mathrm{~kg} \mathrm{ha}^{-1}$ loose ash (dry basis), and $100 \mathrm{~kg} \mathrm{~N} \mathrm{ha}^{-1}$ of urea in pellet form. Changes in understory vegetation cover were observed. There was a significant $(p<0.05)$ effect of nitrogen and wood ash plus nitrogen application on understory vegetation community composition, with nitrogen application having the greatest effect. Discriminant function analysis indicated a differential response of species group to ash/ nitrogen treatments, though the effect size was small. We conclude that short-term changes to understory vegetation are minimal when these two ashes were applied at a rate of $5000 \mathrm{~kg} \mathrm{ha}^{-1}$. Continued monitoring will determine if any long-term effects become apparent with time.
\end{abstract}

Key words: bottom ash, ground vegetation, waste management, soil amendment, biodiversity, hybrid spruce, boreal forest

\section{RÉSUMÉ}

La cendre de bois peut être utilisée comme amendement des sols dans les écosystèmes forestiers pour compenser la perte d'éléments nutritifs, améliorer l'acidité du sol, augmenter la croissance des arbres et réduire les accumulations inutiles dans les sites d'enfouissement. Deux plantations d'épinettes hybrides (Picea glauca X engelmannii) dans l'intérieur de la Colombie-Britannique ont été traitées avec deux types de cendres de bois résultant de la bioénergie forestière (cendres de chaudière à haute teneur en carbone et cendres de gazéifieur à faible teneur en carbone) avec ou sans engrais à base d'azote, dans un dispositif d'analyse factorielle en bloc à 2 niveaux. Des traitements aux cendres et à l'azote ont été appliqués sur des placettes (rayon de $8,0 \mathrm{~m}$ ) à raison de $5000 \mathrm{~kg} \mathrm{ha}^{-1}$ de cendres en vrac (base sèche) et de $100 \mathrm{~kg} \mathrm{~N} \mathrm{ha}^{-1} \mathrm{~d}^{\text {uurée }}$ sous forme granulaire. Des changements dans la couverture végétale du sous-étage ont été observés. Il y avait un effet significatif $(\mathrm{p}<0,05)$ de l'application de l'azote et de la cendre de bois avec l'azote sur la composition de la communauté végétale du sous-étage, l'application de l'azote ayant le plus grand effet. L’analyse de la fonction discriminante a révélé la séparation des groupes d'espèces en fonction des traitements à la cendre/ azote, bien que l'effet était faible. Nous concluons que les changements dans la végétation du sous-étage, à court terme, sont minimes lorsque les cendres sont appliquées à un taux de $5000 \mathrm{~kg} \mathrm{ha}^{-1}$. Une surveillance continue déterminera si des effets à long terme se manifestent avec le temps.

Mots clés: Cendre de bois résiduelle, végétation au sol, gestion des déchets, amendement du sol, biodiversité, épinette hybride, forêt boréale

\section{Introduction}

Rising atmospheric concentrations of greenhouse gases have encouraged a global shift from fossil fuel-based energy to renewable energy, including bioenergy systems (Steenari and Lindqvist 1997; Hannam et al. 2016). Innovative wood ash management strategies are needed as the current standard practice of landfill disposal is not sustainable nor environmentally responsible (Brunner et al. 2004; Hannam et al. 2017). One such approach is to apply wood ash as a soil amendment to forest ecosystems for one or more of the following reasons: (i) to replace nutrients removed through biomass removal; (ii) to counteract the acidifying effects of atmospheric deposition and forest harvesting; (iii) to enhance tree growth; and/or, (iv) to emulate some of the effects of wildfire on soil properties (Hannam et al. 2018).

Wood ash contains most essential nutrients required for plant growth, including $\mathrm{Ca}, \mathrm{Mg}, \mathrm{K}$, and $\mathrm{P}$, but excludes nitrogen $(\mathrm{N})$ as it is largely volatilized during combustion (Perkiömäki and Fritze 2002; Nieminen et al. 2005; Pitman 2006; Maljanen et al. 2006). When wood ash is surfaceapplied to the forest floor, nutrients gradually dissolve and leach downward into organic and mineral horizons allowing

\footnotetext{
${ }^{1}$ University of Northern British Columbia, 3333 University Way, Prince George, BC V2N 4Z9 Canada

*Corresponding author email: hugues.massicotte@unbc.ca

${ }^{2}$ Current address: Laurentian University, Sudbury, ON P3E 2C6 Canada

${ }^{3}$ Omineca Research and Stewardship Team, British Columbia Ministry of Forests Lands and Natural Resource Operations and Rural

Development, Prince George, BC V2N 4W5 Canada
} 
for uptake by plants. Wood ash is alkaline with a $\mathrm{pH}$ typically ranging from $8-13$, making it effective for neutralizing soil acidity (Augusto et al. 2008). Ash application has been shown to increase soil base saturation and soil $\mathrm{pH}$ when applied to mineral and peat soils, subsequently mitigating effects of soil acidification (Ohno and Erich 1998; Maljanen et al. 2006; Reid and Watmough 2014). Increased pH can increase $\mathrm{pH}$-dependent cation exchange capacity (CEC) in soil (Augusto et al. 2008), and can alter soil microbial processes (Zimmermann and Frey 2002; Saarsalmi et al. 2004, 2012; Maljanen et al. 2006).

Understory vegetation is critical to forest ecosystem functioning as it provides structure and influences nutrient availability, litter decomposition, soil microbial activity, and retains soil moisture (Nilsson and Wardle 2005). Although herbaceous understory vegetation makes up less than $1 \%$ of total forest biomass, it can contain up to $90 \%$ of forest species, and is therefore essential for biodiversity in forest ecosystems (Gilliam 2007). As species composition of ground vegetation is correlated with soil fertility and characteristics, it can be inferred that the presence of wood ash will affect understory vegetation through soil interactions (Arvidsson et al. 2002).

Nitrogen is the main limiting nutrient in the growth of boreal forests and $\mathrm{N}$ application has shown to increase the quality and quantity of growth in Finnish conifer stands (Saarsalmi et al. 2004). The addition of $\mathrm{N}$ fertilizer with wood ash application can compensate for $\mathrm{N}$ deficiencies and facilitate nutrient uptake. Existing research on the long-term response of vegetation to wood ash has shown various outcomes. Bryophyte cover has generally been observed to decrease following wood ash application due to visible damage from ash application and increased litter cover (Jacobson and Gustafsson 2001; Moilanen et al. 2002; Ozolinčius et al. 2007). In contrast, Arvidsson et al. (2002) noted that bryophytes remained unaffected for up to five years after ash application. In other studies, grasses and herbs appear to respond positively to ash application, whereas dwarf shrubs and shrubs either have a neutral (Arvidsson et al. 2002; Park et al. 2005; Ozolinčius 2007) or a negative response (Moilanen et al. 2002). Ozolinčius et al. (2007) found that vascular plant cover showed no change when treated with both wood ash and nitrogen fertilizer. Due to the variability in understory responses to treatments, additional studies are required to understand the effect wood ash has on understory vegetation community dynamics. Short-term response of vegetation to wood ash may be used to infer future changes in cover and species composition.

Wood ash application in B.C. forests has the potential to be beneficial through increasing stand yield, ameliorating the acidifying effects of forest harvesting and/or by replenishing nutrients to harvested stands (Hannam et al. 2018). In British Columbia, some types of wood ash are not currently recognized as soil amendments under the current Code of Practice for Soil Amendments; these ashes (e.g., bottom ash) may need a permit or approval prior to use in forest or agricultural systems; specific chemical and physical criteria need to be met prior to government authorization for land application (Government of British Columbia 2007; Hannam et al. 2016). The addition of ash to soil and the subsequent appraisal on understory vegetation has been conducted pri- marily in Nordic countries (Jacobson and Gustafsson 2001; Arvidsson et al. 2002; Moilanen et al. 2002; Ozolinčius et al. (2007). It is critical to study the effects of wood ash on vegetation native to B.C. in order to fully understand the effect of ash applications on Canadian ecosystems.

This study examined the short-term response of understory vegetation in conifer plantations following the application of high-carbon boiler ash, low-carbon gasifier ash, and conventional nitrogen fertilizer (urea 46-0-0). One growing season following treatment of wood ash and wood ash plus nitrogen, the objectives of this study were to: i) determine if ground vegetation cover in selected B.C. hybrid spruce stands differed (increased or decreased); ii) document how species composition of ground vegetation responded to the treatments; and, iii) provide baseline information on vegetative species present across study sites as part of a long-term study.

\section{Materials and methods}

\section{Site description and trial establishment}

The study was conducted at the Aleza Lake Research Forest (ALRF) located $\sim 60 \mathrm{~km}$ northeast of Prince George, B.C. in the Willow Wet Cool Sub-Boreal Spruce (SBSwk1) subzone/variant of the biogeoclimatic ecosystem classification (BEC) of B.C. Experimental treatments were applied to two sites in the ALRF: the North Site and the South Site, located $\sim 2.5 \mathrm{~km}$ apart (Domes et al. 2018). These sites are dominated by hybrid spruce (Sxw) (Picea glauca $x$ engelmannii Parry $\mathrm{x}$ Engelm.) and subalpine fir (Abies lasiocarpa (Hook.) Nutt.) on glaciolacustrine fine-textured Gray Luvisolic soils with associated Luvic Gleysols, which are common in this area (Arocena et al. 1999). The North Site (54.086 deg. N x 122.090 deg. W) is classified as a "Sxw-Oak Fern" BEC ecosystem, and was clearcut and planted with hybrid spruce in 1997 with no site preparation. The South Site (54.071 deg. $\mathrm{N} x 122.0080$ deg. W) is classified as an "Sxw-Oak Fern" BEC ecosystem transitioning to "Sxw-Oak Fern-Twinberry" and was clearcut and broadcast burned in 1990 and planted with hybrid spruce in 1991 (DeLong 2003; Domes et al. 2018).

Two types of wood ash were used in this study. A high carbon (29.7\% total C) bottom ash was obtained from Canfor Pulp and Paper PG Pulp Boiler \#2 Bioenergy Plant, a fixedbed industrial boiler. A low carbon (7.3\% total C) bottom ash was obtained from the University of Northern British Columbia (UNBC) 4.4 MW Bioenergy Plant, a Nexterra updraft gasifier. The Canfor wood ash was produced by the combustion of non-fibrous components of sawmill residuals retrieved after fibre separation, and the UNBC wood ash was produced by gasification of softwood sawmill residuals (see Domes et al. (2018) for a detailed characterization for both these ashes as well as the receiving soils).

Treatments were applied at the ALRF in a randomized block design from May 25-29, 2015. There were three ash treatments (no ash, UNBC ash, Canfor ash) x two nitrogen treatments (no nitrogen, nitrogen) $\mathrm{x}$ three replicates at each site, resulting in 18 individual plots at each site (North and South, 36 plots overall). Each plot was circular with an outer radius of $8.0 \mathrm{~m}(0.0201 \mathrm{ha})$ and an inner radius of $5.64 \mathrm{~m}$ $(0.0099 \mathrm{ha})$. Ash was applied to the forest floor at a $5000 \mathrm{~kg}$ ash ha $^{-1}$ (dry ash equivalent) using a shovel out to the $8.0 \mathrm{~m}$ radius. Nitrogen was broadcast applied at $100 \mathrm{~kg} \mathrm{~N} \mathrm{ha}^{-1}$ in the form of pelletized urea using hand scoops out to the $8.0 \mathrm{~m}$ radius. 


\section{Sample collection}

Vegetation samples were collected from June $13^{\text {th }-} 23^{\text {rd }} 2016$, one growing season after ash application. For each of the 36 plots, a list of all plant species growing within the $8.0 \mathrm{~m}$ outer plot radius was determined. Percent cover of plant species and lichen genera growing within each inner $5.64 \mathrm{~m}$ plot radius was determined. Each plot was divided into four quadrats (north, east, south, west) measured from plot centre. A $1-\mathrm{m}^{2}$ quadrat (PVC pipe) was placed along each transect line $3.0 \mathrm{~m}$ from plot center to reduce placement bias. Percent cover was estimated visually within the $1-\mathrm{m}^{2}$ square. Vascular plants and mosses were identified to species; lichens were treated more generally and only identified to genus (MacKinnon et al. 1992).

\section{Statistical analyses}

The influence of ash and nitrogen treatments on vegetation percent cover was evaluated using a two-way analysis of variance (ANOVA) structure within a mixed-effects model framework. Ash and nitrogen treatments were input as fixed effects, and site (North or South) was input as a random effect. To evaluate how ash and/or nitrogen influence understory community composition, individual species were aggregated into species groups (bryophytes, lichens, forbs, grasses, shrubs, and tree seedlings). To improve the multivariate normality of the data and to facilitate ecological interpretation, prior to analysis, the percent cover of each species group was transformed using a Hellinger transformation (Legendre and Gallagher 2001). Homogeneity of withingroup covariance was evaluated using Anderson (2006) testing method, with the primary predictive groups (ash and nitrogen) and the interaction term conforming. Treatment effects on community composition were tested using a redundancy analysis (RDA) approximation of a MANOVA (Bocard et al. 2011). Ash and nitrogen additions were represented as orthogonal Helmert contrasts and were used to test the main and interaction effects using an RDA permutation test $(\mathrm{n}=1000)$ (Bocard et al. 2011). A linear discriminant function analysis was performed to characterize how the species groups responded to the ash and/or nitrogen treatments. All analyses were performed in R (R Core Team 2019) using the package biotools (da Silva et al. 2017), vegan (Oksanen et al. 2019), and nlme (Pinheiro et al. 2019)

\section{Results}

Ninety-five species were found across all plots within the 8.0 $\mathrm{m}$ radius $^{1}$. However, only 81 of these were accounted for by the $1-\mathrm{m}^{2}$ quadrats when describing percent cover in each plot. An analysis of variance (ANOVA) determined that there was no significant difference in total cover of all species treated with ash and/or nitrogen across all plots (Fig. 1, Table 1)

In order to gain more insight into how nitrogen application, and nitrogen and ash application, influenced community composition, we aggregated our individual species percent cover data into six broader species groups and conducted an RDA permutation test: bryophytes $(n=13)$, lichens $(n=3)$, forbs $(n=41)$, grasses $(n=4)$, shrubs $(n=15)$, and tree seedlings $(n=5)$. We found a significant interaction

\footnotetext{
${ }^{1}$ See supplementary Table S1 for full species list
}

between ash and nitrogen addition (Table $2, \mathrm{p}=0.028$ ), with ash and nitrogen in combination principally impacting lichen and shrub percent cover (Fig. 2, Fig. 4). We then evaluated the addition of ash as a single factor and found that it has a marginally non-significant impact on community composition (Table $2, p=0.086$, Fig. 3 ). Percent cover was highly variable between ash and/or nitrogen treatments in tree seedlings, grasses, and lichens (Fig. 2).

To evaluate how ash addition influenced community composition, we conducted a linear discriminant function analysis using the percent cover of the six species groups. The first axis of the discriminant function analysis separated the ash treatments primarily based on differences in lichen cover, followed by differences in tree seedling cover and shrubs (Fig. 3, Table 3). Lichen cover and tree seedling cover were both generally higher in plots with no ash treatments (Fig. 2).

We conducted a second linear discriminant function analysis to evaluate how ash and/or nitrogen treatments influenced community composition as measured using the percent cover of the six species groups. Treatments were primarily separated by lichen cover, with lichen cover generally higher in control plots (Fig. 4, Table 3). Bryophytes, forbs, shrubs, and grasses did not provide much differentiation between ash and/or nitrogen treatments (Fig. 4, Table 3). Cover of lichens was highest in plots receiving no ash and no nitrogen and was lowest in plots receiving nitrogen but no ash (Fig. 2). Tree seedling cover was highest in control plots (no ash, no nitrogen) and in plots treated with no ash and nitrogen, and lowest in plots treated with Canfor ash, Canfor ash and nitrogen, and UNBC ash (Fig. 2). Variation in cover between ash and/or nitrogen treatments within bryophyte, shrub, grass, and forb species groups were minor.

\section{Discussion}

Changes in plant species diversity across all plots was minor, possibly due to measurements taken after only one growing season post treatment application in May $2015^{2}$. There were no pre-treatment measurements of species diversity which would have been useful in documenting changes in diversity.

The application of UNBC ash and Canfor ash, when applied with and without nitrogen, did not have a significant effect on total species cover across all plots (Table 1). However, nitrogen in combination with either Canfor ash or UNBC ash had significant effects on species group cover (Table 2). From these results, we can infer that ash and nitrogen application is not influencing total species cover in each plot but may be altering species composition. Discriminant function analysis separated species groups based on ash and/or nitrogen treatments but the effect size was reasonably small. Treatments were primarily separated by shifts in lichen cover (Fig. 4, Table 3). There were decreases in lichen cover in plots treated with nitrogen, nitrogen and UNBC ash, and nitrogen and Canfor ash when compared to control plots (Fig. 2). Differences in lichen cover between plots may be due to natural variation in species composition pre-treatment; however, exposure to high concentration of nitrogen has been shown to have toxic effects on lichen (Johansson et al. 2012). Lichens have efficient absorption systems that result in

\footnotetext{
${ }^{2}$ See supplementary Table S2 for number of species identified per plot
} 


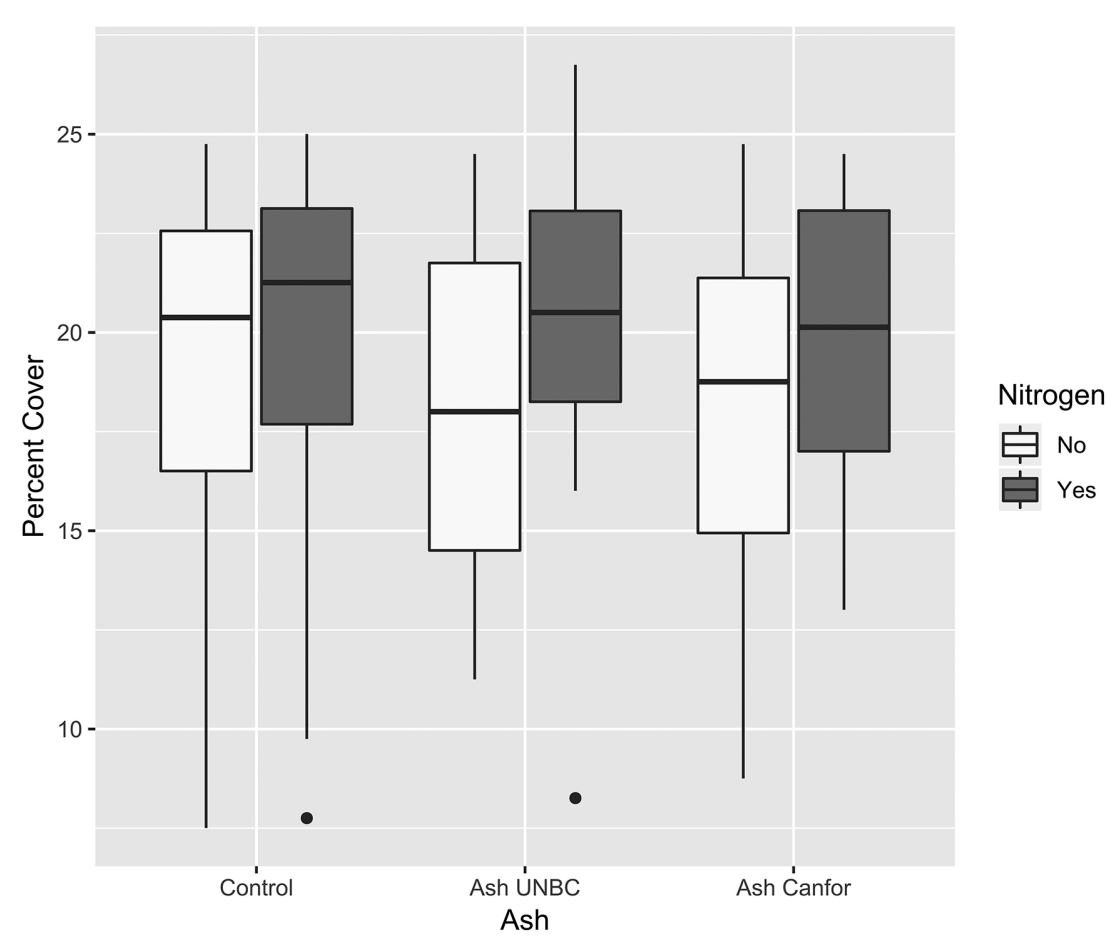

Fig. 1. Percent cover of all species of understory vegetation in plots treated with ash and/or nitrogen after one growing season. Boxplots indicate the median, $25^{\text {th }}$ and $75^{\text {th }}$ percentiles, while the whiskers indicate the range of percent cover observed per treatment. Outliers are indicated by dots.

Table 1. Two-way ANOVA results from a mixed-effects linear model of percent cover of all species in understory vegetation treated with ash and/or nitrogen after one growing season

\begin{tabular}{llccc}
\hline Response & Treatment & Df & F-value & $\boldsymbol{p}$-value \\
\hline Percent Cover & Ash & 2 & 0.0755 & 0.927 \\
& Nitrogen & 1 & 3.29 & 0.0795 \\
& Ash:Nitrogen & 2 & 0.330 & 0.722 \\
\hline
\end{tabular}

Table 2. Redundancy analysis (RDA) permutation test results of percent cover of grouped species in understory vegetation (lichens, bryophytes, tree seedlings, shrubs, forbs, and grasses) treated with ash and/or nitrogen after one growing season. Significant values $(p<0.05)$ are marked by *

\begin{tabular}{llcccc}
\hline Response & Treatment & Df $_{\text {model }}$ & F-value & Df $_{\text {residual }}$ & p-value \\
\hline \multirow{2}{*}{ Percent Cover } & Ash & 2 & 0.75 & 138 & 0.635 \\
& Nitrogen & 1 & 2.01 & 138 & 0.086 \\
& Ash:Nitrogen & 2 & 2.25 & 138 & $0.028^{*}$ \\
\hline
\end{tabular}

rapid accumulations of water and dissolved elements, including nitrogen, sulphur, and heavy metals, thereby making them sensitive indicators of environmental pollution (Salemaa et al. 2004). Salemaa et al. (2004) found that lichens nearest to the Harjavalta copper-nickel smelter in Finland had elevated concentrations of nitrogen, sulphur, and heavy
Table 3. Coefficients of the first two linear discriminants from a discriminant function analysis separating plant community composition by ash treatment (corresponding to Fig. 3) and by ash and nitrogen treatments (corresponding to Fig. 4)

\begin{tabular}{lrrrrr}
\hline & \multicolumn{2}{c}{$\begin{array}{c}\text { Grouping by } \\
\text { Ash treatment }\end{array}$} & & \multicolumn{2}{c}{$\begin{array}{c}\text { Grouping by Ash } \\
\text { and Nitrogen treatment }\end{array}$} \\
\cline { 2 - 3 } \cline { 5 - 6 } \cline { 5 - 6 } & LD1 & LD2 & & LD1 & LD2 \\
\hline Bryophytes & 2.45 & -2.89 & & -0.33 & 0.87 \\
Lichens & -7.32 & 3.13 & & 10.32 & -7.74 \\
Forbs & 2.30 & -4.12 & & 1.70 & -2.58 \\
Grasses & -3.22 & -4.66 & & -2.39 & -4.73 \\
Shrubs & 3.95 & 1.03 & & -2.78 & -2.83 \\
Trees & -3.87 & 2.55 & & 0.55 & -4.85 \\
\hline
\end{tabular}

metals compared to lichens in background areas. Johansson et al. (2012) examined the effects of nitrogen deposition over four growing seasons in nitrogen-poor boreal forests, and found that nitrogen addition altered lichen community structure and decreased species richness. As nitrogen stimulates algal growth, nitrogen deposition may alter the photobiont: mycobiont ratio in lichens, causing a reduction in stability (Johansson et al. 2011). Jacobson and Gustafsson (2001) reported a decrease in lichen cover over five years in response to wood ash application, whereas Olsson and Kelher (2006) reported a decrease in lichen cover 15 years postnitrogen fertilization. Though short-term response of lichen to ash application alone showed no significant change in 

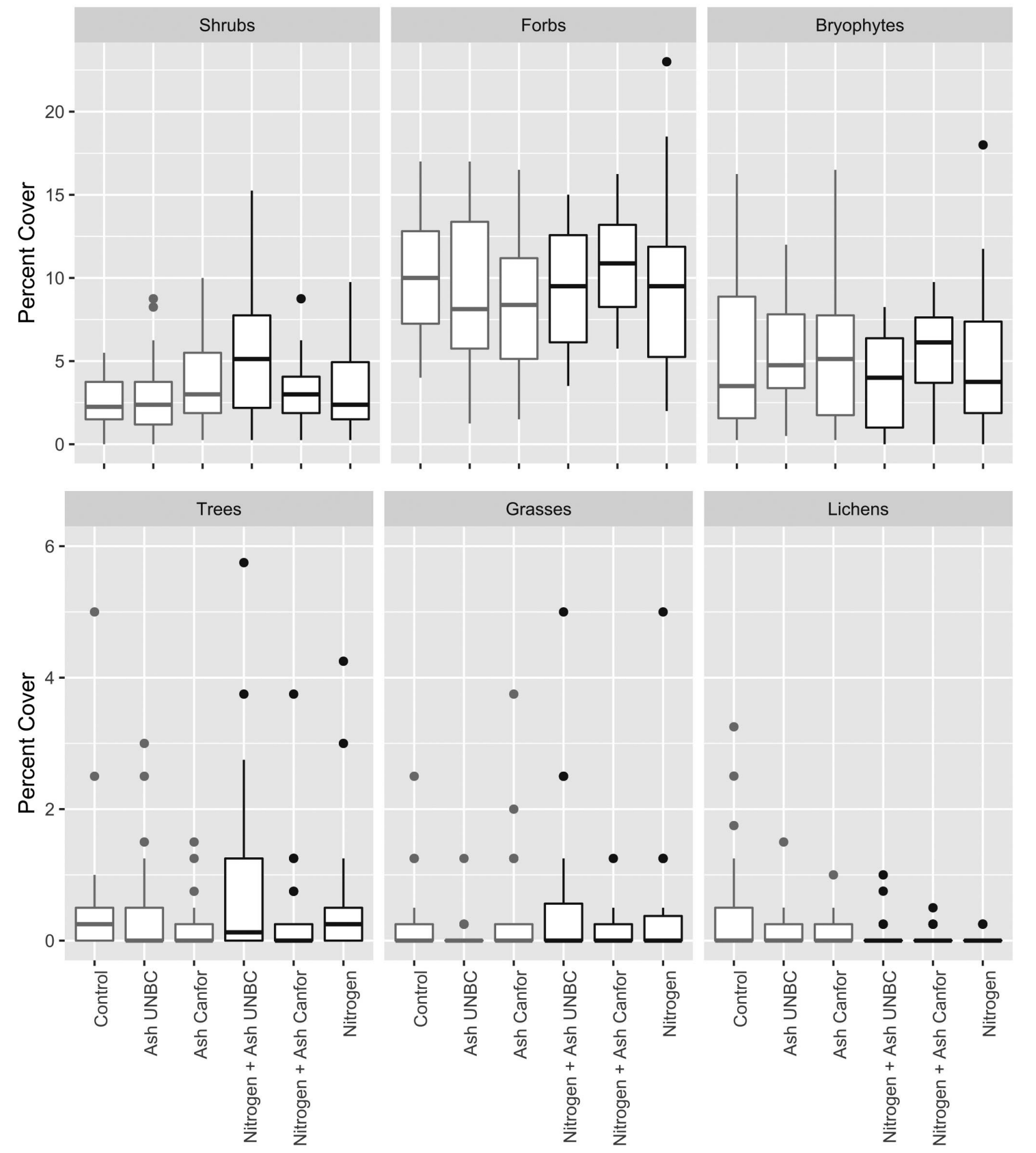

Fig. 2. Percent cover of species groups (shrubs, forbs, bryophytes, trees, grasses, and lichens) treated with ash and/or nitrogen after one growing season. Boxplots indicate the median, $25^{\text {th }}$ and $75^{\text {th }}$ percentiles, while the whiskers indicate the range of percent cover. Outliers are indicated by dots. 


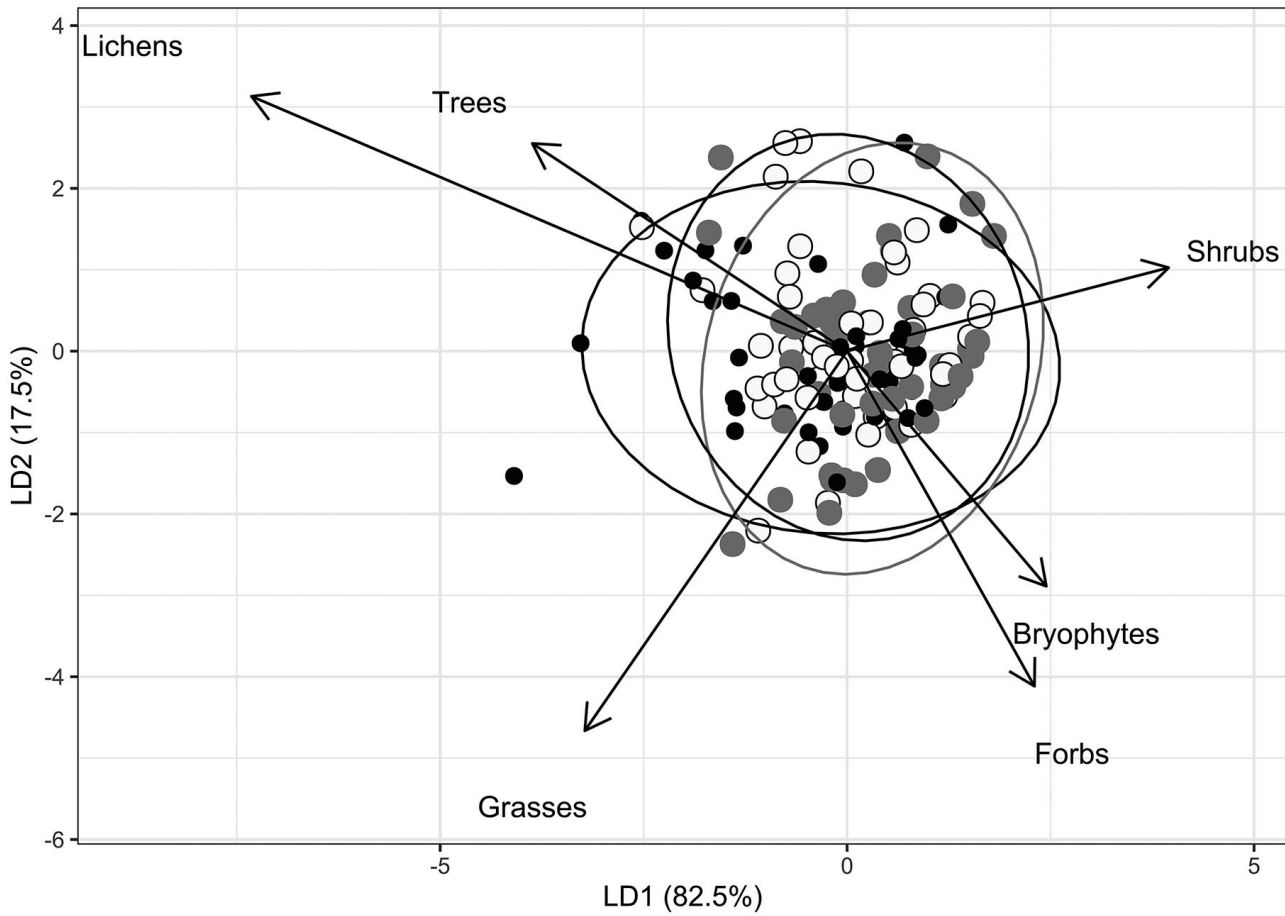

\section{Groups \\ - None \\ Canfor \\ UNBC}

Fig. 3. Discriminant function analysis of ash application on community composition. Community composition was evaluated using the percent cover of each species groups (lichens, bryophytes, tree seedlings, shrubs, forbs, and grasses). Separation of each plot, by ash treatment, is shown along the first and second discriminant function (LD1 and LD2), with the 95\% confidence bounds represented by an ellipse for each treatment. Ash treatments are separated primarily by species group "Lichens", and secondly by "Trees" as indicated by the ordination vector length.

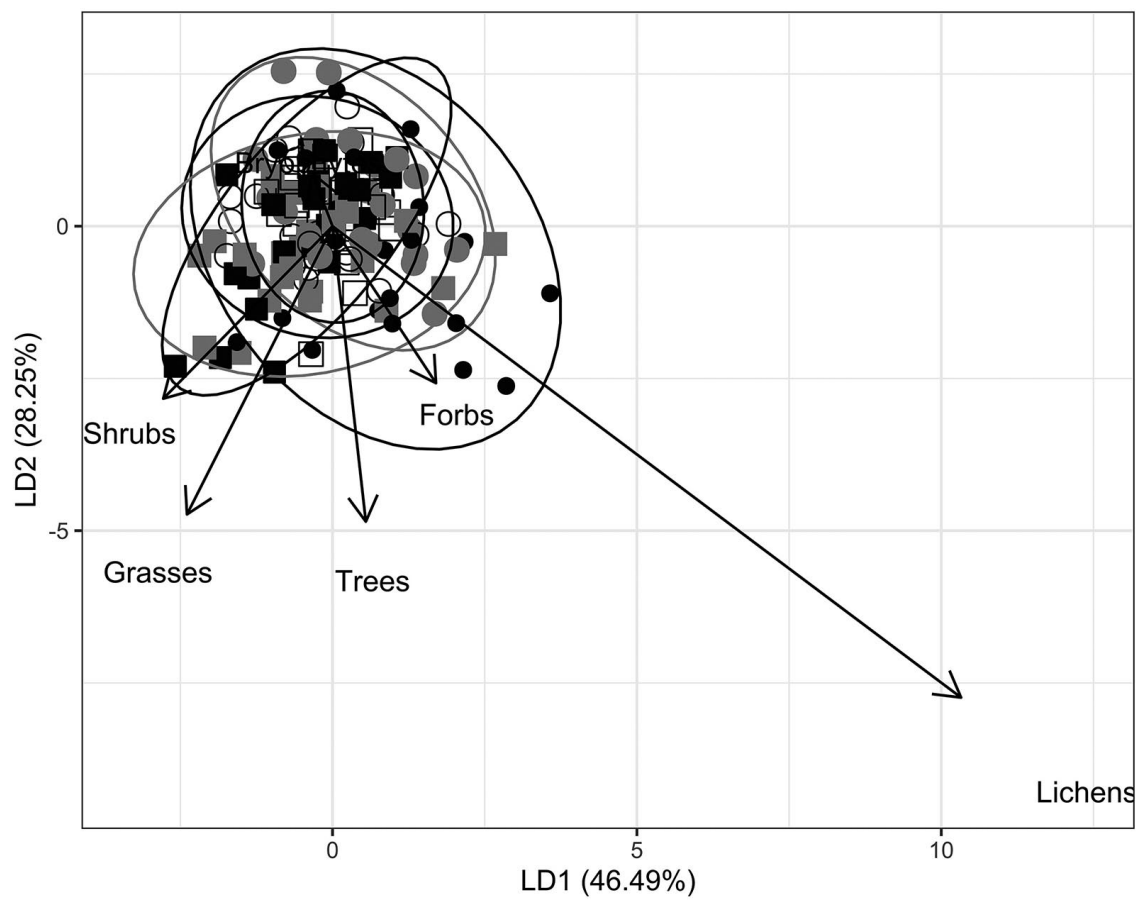

\section{Groups}

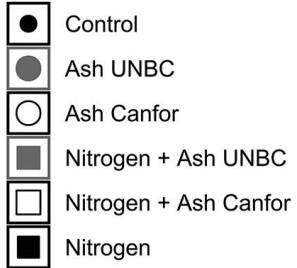

Fig. 4. Discriminant function analysis of ash and/or nitrogen application on community composition. Community composition was evaluated using the percent cover of each species groups (lichens, bryophytes, tree seedlings, shrubs, forbs, and grasses). Separation of each plot, by ash and nitrogen treatment, is shown along the first and second discriminant function (LD1 and LD2), with the 95\% confidence bounds represented by an ellipse for each treatment. Ash and nitrogen treatments are separated primarily by species group "Lichens", and secondly by "Trees" as indicated by the ordination vector length. 
cover, the long-term sensitivity of lichen to nitrogen needs to be examined further in future assessments.

There was no significant effect of ash application by itself on the cover of species groups, but a significant effect of ash in combination with nitrogen, suggesting that nitrogen is most likely the limiting factor. Nitrogen addition may have increased the cover of vascular plants, particularly for bilberry Vaccinium myrtillus L., in Scots pine stands (Pinus sylvestris L.) in Sweden (Jacobson and Gustafsson 2001). Increased vascular cover resulting from nitrogen addition could potentially increase litter cover, which in turn may influence the cover of bryophytes and lichens both by physically covering species and by increased nutrient availability from higher decomposition rates (Jacobson and Gustafsson 2001). Variation in tree seedling cover is likely due to pretreatment planting density, as changes to tree growth after one year post-ash application are unlikely (Fig. 2).

Our study shows no significant effects of wood ash on understory cover when applied without nitrogen, a finding supported by Pitman (2006), who concluded that wood ash is unlikely to have an effect where nitrogen is limiting. Ash application has been shown to influence nutrient availability in soil by increasing decomposition rates, increasing cation exchange capacity and base saturation, and increasing $\mathrm{pH}$ (Saarsalmi et al. 2004, 2012, 2014; Augusto et al. 2008; Brais et al. 2015; Domes et al. 2018). Arvidsson et al. (2002) found that vascular plant cover after ash application on Norway spruce (Picea abies (L.) H. Karst.) stands in Sweden both increased and decreased, depending on the species examined. They theorized that decreases in cover might have been due to high soluble salt concentrations in soil from applied fertilizers. Moilanen et al. (2002) found that grasses and herbs increased in cover whereas shrubs and mosses decreased in cover following ash application on a drained pine mire in Finland. Nutrients were more available to grasses and herbs in ash-treated plots, allowing for increased nutrient uptake when compared to shrubs and mosses.

Arvidsson et al. (2002) hypothesized that changes in cover may be due to changes in species competition: species that respond positively to ash application may subsequently outcompete other species. As our study observed changes in cover of species groups, competition may be a driving factor in differences between bryophytes, lichens, grasses, forbs, shrubs, and trees. Although we did not perform an in-depth statistical analysis on individual species, we can hypothesize that changes would be similar to those observed in species groups.

\section{Conclusions}

The results of this short-term field study suggest that ash can be applied as a soil amendment without detrimental effects on ground vegetation. We detected minimal changes in ground vegetation cover in response to the application of low carbon UNBC ash, high carbon Canfor ash, and nitrogen after one growing season. Changes in species composition were likely due to changes in both soil fertility resulting from wood ash application, and increased nitrogen availability from nitrogen application. Changes in cover and species composition may impact ecosystem function on a larger scale. Short-term responses of ground vegetation in response to wood ash and nitrogen application may influence long- term outcomes. Due to this possibility, monitoring on ground vegetation in ash-treated plots in the Aleza Lake Research Forest to document any long-term changes in species composition and cover from ash and nitrogen application will continue.

\section{Acknowledgements}

We are grateful to all individuals who helped establish the Aleza Lake Research Forest (ALRF) ash plots: M. Jull, C. Chisholm, S. Gonzalez, K. Domes, E. Rehl, K. Reimer, S. Helle, E. Teen, L. Tackaberry, and W. McGill. Many thanks to Michael Jull and Colin Chisholm for helping with sampling design and allowing Saskia Hart to conduct her research while at the ALRF. Thanks also to Samantha Gonzalez, Rachelle Winsor, and John Mainville for help during sample collection, to J. Orlowsky and D. Thompson (UNBC Enhanced Forestry Laboratory) for providing space, equipment and support during ash collection and handling, and to Canfor Pulp Limited for supplying ash, transportation, and chemical analyses. We acknowledged financial support from Canfor Pulp Grants Program, NSERC (Discovery Grant and Collaborative Research and Development Grant), and the Fraser Basin Council (via Terry Robert).

\section{References}

Anderson, M.J. 2006. Distance-Based Tests for Homogeneity of Multivariate Dispersions. Biometrics 62:245-253. doi: 10.1111/ j.1541-0420.2005.00440.x

Arocena, J.M. and P.T. Sanborn. 1999. Mineralogy and genesis of selected soils and their implications for forest management in central and northeastern British Columbia. Can. J. Soil Sci 79(4): 571592. doi: 10.4141/S98-071

Arvidsson, H., T. Vestin and H. Lundkvist. 2002. Effects of crushed wood ash application on ground vegetation in young Norway spruce stands. For. Ecol. Manag. 161: 75-87.doi: 10.1016/S0378-1127(01)00482-0

Augusto, L., M.R. Bakker and C. Meredieu. 2008. Wood ash applications to temperate forest ecosystems-potential benefits and drawbacks. Plant Soil 306(1-2): 181-198. doi: 10.1007/s11104-0089570-Z

Bocard, D., F. Gillet and P. Legendre. 2011. Numerical Ecology with R. Springer-Verlag, New York. doi: 10.1007/978-1-4419-7976-6 Brais, S., N. Bélanger and T. Guillemette. 2015. Wood ash and N fertilization in the Canadian boreal forest: Soil properties and response of jack pine and black spruce. Forest Ecol. Manage. 348: 114. doi: 10.1016/j.foreco.2015.03.021

Brunner, I., S. Zimmermann, A. Zingg and P. Blaser. 2004. Wood-ash recycling affects forest soil and tree fine-root chemistry and reverses soil acidification. Plant Soil 267(1-2): 61-71. doi: 10.1007/s11104-005-4291-z

da Silva, A.R., G. Malafaia and I.P.P. Menezes. (2017). Biotools: An $\mathrm{R}$ function to predict spatial gene diversity via an individualbased approach. Genet Mol Res. 16(2): gmr16029655. doi: 10.4238/gmr16029655

DeLong, C. 2003. A field guide to site identification and interpretation for the southeast portion of the Prince George Forest Region. Res. Br., B.C. Min. For., Victoria, B.C. Land Manage. Handbk. No. 51. Available from: https://www.for.gov.bc.ca/hfd/pubs/Docs/ Lmh/Lmh51.htm

Domes, K.A., T.D. Zeeuw, H.B. Massicotte, C. Elkin, W.B. McGill, M.J. Jull, C.E. Chisholm and P. M. Rutherford. 2018. Short-term changes in spruce foliar nutrients and soil properties in response to wood ash application in the sub-boreal climate zone of British Columbia. Can. J. Soil Sci. 98(2):246-263. doi: 10.1139/cjss2017-0115 
Gilliam, F.S. 2007. The ecological significance of the herbaceous layer in temperate forest ecosystems. Bioscience 57(10):845-858. doi: 10.1641/B571007

Government of British Columbia. 2007. British Columbia Code of Practice for Soil Amendments under the Environmental Management Act and the Public Health Act. Available from: http:// www.bclaws.ca/Recon/document/ID/freeside/210_2007

Hannam, K.D., C. Deschamps, M. Kwiaton, L. Venier and P.W. Hazlett. 2016. Regulations and guidelines for the use of wood ash as a soil amendment in Canadian forests. Natural Resources Canada, Canadian Forest Service, Great Lakes Forestry Centre. Information Report No. GLC-X-17 2016. [Online], Available: https://cfs. nrcan.gc.ca/publications? $\mathrm{id}=37781$

Hannam, K.D., L. Venier, E. Hope, D. McKenney, D. Allen and P.W. Hazlett. 2017. AshNet: Facilitating the use of wood ash as a forest soil amendment in Canada. For. Chron. 93(1): 17-20. doi: 10.5558/tfc2017-006

Hannam, K.D., L. Venier, D. Allen, C. Deschamps, E. Hope, M. Jull, M. Kwiaton, D. McKenney, P.M. Rutherford and P.W. Hazlett. 2018. Wood ash as a soil amendment in Canadian forests: What are the barriers to utilization? Can. J. For. Res. 48(4): 442-450. doi: 10.1139/cjfr-2017-0351

Jacobson, S. and L. Gustafsson. 2001. Effects on ground vegetation of the application of wood ash to a Swedish Scots pine stand. BAAE. 2(3): 233-241. doi: 10.1078/1439-1791-00050

Johansson, O., K. Palmqvist and J. Olofsson. 2012. Nitrogen deposition drives lichen community changes through differential species responses. Glob. Change Biol. 18(8): 2626-2635. doi: 10.1111/j.1365-2486.2012.02723.x

Johansson, O., J. Olofsson, R. Giesler and K. Palmqvist. 2011. Lichen responses to nitrogen and phosphorus additions can be explained by the different symbiont responses. New Phytol. 191: 795-805. doi: 10.1111/j.1469-8137.2011.03739.x

Legendre, P. and E.D. Gallagher. 2001. Ecologically meaningful transformations for ordination of species data. Oecologia 129:271280. doi: $10.1007 / \mathrm{s} 004420100716$

MacKinnon, A., J. Pojar and R. Coupé (Eds.). 1992. Plants of Northern British Columbia. Lone Pine Publishing \& BC Ministry of Forests.

Maljanen, M., H. Nykänen, M. Moilanen and P.J. Martikainen. 2006. Greenhouse gas fluxes of coniferous forest floors as affected by wood ash addition. For. Ecol. Manag. 237(1): 143-149. doi: 10.1016/j.foreco.2006.09.039

Moilanen, M., K. Silfverberg and T.J. Hokkanen. 2002. Effects of wood ash on the tree growth, vegetation and substrate quality of a drained mire: A case study. For. Ecol. Manag. 171(3): 321-338. doi: 10.1016/S0378-1127(01)00789-7

Nieminen, M., S. Piirainen and M. Moilanen. 2005. Release of mineral nutrients and heavy metals from wood and peat ash fertilizers: Field studies in Finnish forest soils. Scand. J. For. Res. 20(2): 146-153. doi: 10.1080/02827580510008293

Nilsson, M.C. and D.A. Wardle. 2005. Understory vegetation as a forest ecosystem driver: evidence from the northern Swedish boreal forest. Front. Ecol. Environ. 3(8): 421-428. doi: 10.1890/15409295(2005)003[0421:UVAAFE]2.0.CO;2

Ohno, T. and M. S. Erich. 1990. Effect of wood ash application on soil $\mathrm{pH}$ and soil test nutrient levels. Agric. Ecosyst. Environ. 32(3): 223-239. doi: 10.1016/0167-8809(90)90162-7

Oksanen, J., F. Guillaume Blanchet, M. Friendly, R. Kindt, P. Legendre, D. McGlinn, P. R. Minchin, R. B. O'Hara, G. L. Simpson, P. Solymos, M. H. H. Stevens, E. Szoecs and H. Wagner (2019). Vegan: Community Ecology Package. R, package version 2.5-5., https://CRAN.R-project.org/package=vegan
Olsson, B.A. and O. Kellner. 2006. Long-term effects of nitrogen fertilization on ground vegetation in coniferous forests. For. Ecol. Manag. 237(1-3): 458-470. doi: 10.1016/j.foreco.2006.09.068

Ozolinčius, R., R. Buožytè and I. Varnagirytė-Kabašinskienè. 2007. Wood ash and nitrogen influence on ground vegetation cover and chemical composition. Biomass Bioenergy. 31(10): 710-716. doi: 10.1016/j.biombioe.2007.06.015

Park, B.B., R.D. Yanai, J.M. Sahm, D.K. Lee and L.P. Abrahamson. 2005. Wood ash effects on plant and soil in a willow bioenergy plantation Biomass Bioenergy. 28(4): 355-365. doi: 10.1016/j.biombioe.2004.09.001

Perkiömäki, J. and H. Fritze. 2002. Short and long-term effects of wood ash on the boreal forest humus microbial community. Soil Biol. Biochem. 34(9): 1343-1353. doi: 10.1016/S0038-0717(02) 00079-2

Pinheiro J, D. Bates, S. DebRoy and D. Sarkar, R Core Team (2019). _nlme: Linear and Nonlinear Mixed Effects Models_. R package version 3.1-139, <URL: https://CRAN.R-project.org/package $=$ nlme $>$.

Pitman, R.M. 2006. Wood ash use in forestry-a review of the environmental impacts. Forestry 79(5): 563-588. doi: 10.1093/forestry/ cpl041

Reid, C. and S.A. Watmough. 2014. Evaluating the effects of liming and wood ash treatment on forest ecosystems through systematic meta-analysis. Can. J. For. Res. 44: 867-885.

R Core Team (2019). R: A language and environment for statistical computing. R Foundation for Statistical Computing, Vienna, Austria. URL https://www.R-project.org/.

Saarsalmi, A., E. Mälkönen, and M. Kukkola. 2004. Effect of wood ash fertilization on soil chemical properties and stand nutrient status and growth of some coniferous stands in Finland. Scand. J. For. Res. 19(3): 217-233. doi: 10.1080/02827580410024124

Saarsalmi, A., A. Smolander, M. Moilanen and M. Kukkola. 2014. Wood ash in boreal, low productive pine stands on upland and peatland sites: Long-term effects on stand growth and soil properties. Forest Ecol. Manage. 327: 86-95. doi: 10.1016/j.foreco.2014.04.031 Saarsalmi, A., A. Smolander, M. Kukkola, M. Moilanen and Saramki, J. 2012. 30-Year effects of wood ash and nitrogen fertilization on soil chemical properties, soil microbial processes and stand growth in a Scots pine stand. Forest Ecol. Manage. 278: 63-70. doi: 10.1016/j.foreco.2012.05.006

Salemaa, M., J. Derome, H.S. Helmisaari, T. Nieminen and I. Vahna-Majamaa. 2004. Element accumulation in boreal bryophytes, lichens and vascular plants exposed to heavy metal and sulphur deposition in Finland. Sci Total Environ. 324: 141-160. doi: 0.1016/j.scitotenv.2003.10.025

Soil Classification Working Group. 1998. The Canadian system of soil classification. Agric. and Agri-Food Can. Publ. 1646 (Revised). 187. [online] Available: http://sis.agr.gc.ca/cansis/publications/ manuals/1998-cssc-ed3/cssc3_manual.pdf

Steenari, B.M. and O. Lindqvist. 1997. Stabilization of biofuel ashes for recycling to forest soil. Biomass Bioenergy 13(1): 39-50. doi: 10.1016/S0961-9534(97)00024-X

Zimmerman, S. and B. Frey. 2002. Soil respiration and microbial properties in an acidic forest soil: effects of wood ash. Soil. Biol. Biochem. 34: 1727-1737. 